\title{
The Result and the Impact of Project IPARD for the Rural and Agricultural Development
}

\author{
Dr. Eda Bezhani \\ University of "Aleksandër Moisiu" Durrës, Faculty of Business, Marketing Department \\ Email: edabezhani82@gmail.com
}

\author{
Doi:10.5901/mjss.2015.v6n2s1p602
}

\begin{abstract}
In implementing the pilot Project, IPARD 2012-2014 for Albania for the agri-food sector, within the IPA 2011 - SARD project, by the Operating Structure in charge (Managing Authority \& Rural Agricultural Development Agency) are followed the activities organized for the implementation of the Grant scheme IPARD-like, which is co-funded by the EU (75\%) and the Albanian Government (25\%) and is implemented by GIZ. The overall objective of this project is the orientation of the Albanian farms in accordance with the European Union standards. Within the first IPA program 2007-2013, during this period, Albania would benefit from the European Union funds. Since Albania has not gained the status of the candidate country, the European Union has given a second chance to Albania, by offering IPARD- Like project, a project which will help the Albanian farmers to absorb the grant funding by the European Union.
\end{abstract}

Keywords: farm orientation, quality of life, gender difference, improving standards.

\section{Introduction}

Albania is still characterized by low productivity of the agriculture and by the rural underdeveloped areas. The farmers and the agri-business operators are not yet prepared to manage the opportunities and challenges arising from the integration of agricultural markets and EU policies. The term 'farmer' is not sufficiently developed in the legislation. The agriculture is labor intensive, with low levels of labor productivity and efficiency, due to the low level of technological progress and the adoption of insufficient knowledge. The total investment in agro-food sector is limited. The advisory and the extension services are relatively weak, and the information systems relating to agriculture are not well developed. Further harmonization with the EU legislation in order to access the EU market opportunities is not yet available on food safety, veterinary and other similar areas. The country lags behind in terms of quality policy operation of the legislation. The funding of agriculture is still limited compared to the needs of the sector and with the other countries in the region. Furthermore, the supporting national measures provide subsidies for domestic production more than the promotion of the competition and the facilitation for loans. The administrative capacity of the country are still low.

In implementing the pilot project, IPARD-Like 2012-2014 for Albania on the agri-food sector, within the IPA 2011 SARD, by the Operating Structure in charge (Managing Authority \& RADA) are followed the activities organized for the implementation of Grant scheme IPARD-like, which co-funded by the EU (75\%) and the Albanian Government (25\%) and implemented by $\mathrm{GIZ}$. The overall objective of this project is the orientation of the Albanian farms in accordance with European Union standards.

The main objectives of this project include:

- Improving the quality of life in rural areas by increasing the competitiveness of the agricultural and agri-food policy through the application of the agricultural and the rural development policies.

- Allocation of the grants for the farmers and the agri-businesses using procedures similar to those of the European Commission IPARD.

These objectives were implemented through two measures:

Measure 1: Investment in Agricultural Farms.

Measure 2: Investment in processing and marketing of agricultural products.

For implementing the project, three calls for applications were organized.

The first call took place in the period 18 December 2012 to 18 February 2013.

Measure 1: During the first call applied a total of 84 subjects, of those 18 came out winners, who are in the process of financing. Referring to the 18 applications received, 15 applications have been at the farm level (the first measure), while 3 other applications are the winner of the second measure. 
Measure 2: Investment in processing and marketing of the agricultural products.

\begin{tabular}{|c|c|c|c|c|c|c|c|}
\hline \multicolumn{3}{|c|}{ First Measure } & \multicolumn{4}{|c|}{ Second Measure } \\
\hline \multirow{2}{*}{ Total } & \multicolumn{3}{|c|}{ From which } & \multirow{2}{*}{ Total } & \multicolumn{3}{c|}{ From which } \\
\cline { 2 - 5 } \cline { 6 - 8 } & Fruits \& Vegetables & Meat & Milk & & Fruits \& Vegetables & Meat & Milk \\
\hline 50 & 24 & 9 & 17 & 34 & 8 & 20 & 6 \\
\hline
\end{tabular}

The second call: It was opened on $30^{\text {th }}$ of April 2013 and continued until $28^{\text {th }}$ of June 2013 and the submitted number of applicants was 65 of which 11 were new farmers.

It is worth mentioning that with the establishment of the criteria was reached the conclusion that the female applicants were $9 \%$, this in the context of alleviating the gender differences.

The number of applicants under the measures:

\begin{tabular}{|c|c|c|c|c|c|}
\hline \multicolumn{3}{|c|}{ First Measure } & \multicolumn{3}{c|}{ Second Measure } \\
\hline \multirow{2}{*}{ Total } & \multicolumn{2}{|c|}{ From whom } & \multirow{2}{*}{ Total } & \multicolumn{2}{c|}{ From whom } \\
\cline { 2 - 3 } \cline { 5 - 6 } & Female & Male & & Female & Male \\
\hline 46 & 2 & 44 & 19 & 4 & 15 \\
\hline
\end{tabular}

From the selection of the list of winners for the second call for the 65 applications were issued 11 winners.

- Some of the reasons for not qualifying the subjects, it was thought they were: the low quality in completing the applications, not the correct completion of the required documentation, the unpaid loans in the Albanian banks, the problems with the land ownership etc.

In this call, the number of beneficiaries of the agricultural machinery is 11 , of which 9 are in the district of Korca, 1 is in the Shkodra district and 1 is in the Elbasan district.

Third Call: It was opened on $17^{\text {th }}$ of March 2014, and continued until $2^{\text {th }}$ of May, 2014.

On the third call, the number of applicants is 106 , of which 16 are new farmers and $16 \%$ of the total applicants are women.

The number of applicants under the measures:

\begin{tabular}{|c|c|c|c|c|c|}
\hline \multicolumn{3}{|c|}{ First Measure } & \multicolumn{3}{c|}{ Second Measure } \\
\hline \multirow{2}{*}{ Total } & \multicolumn{2}{|c|}{ From whom } & \multirow{2}{*}{ Total } & \multicolumn{2}{c|}{ From whom } \\
\cline { 2 - 3 } \cline { 5 - 6 } & Female & Male & & Female & Male \\
\hline 78 & 7 & 71 & 28 & 10 & 18 \\
\hline
\end{tabular}

Currently the selection of the list of the winners for this call is completed.

\section{The impact of this project:}

- In the project IPARD-Like framework, the direct impact, easily distinguishable is that:

- Through the first call from the first Measure (Investment in the agricultural holdings) are created 180 jobs;

- From the second Measure (Investment in processing and marketing of the agricultural products), are created 92 jobs.

- Improving the national standards in accordance with the European standards regarding the fruit and vegetable and dairy meat of the farms at $30 \%$.

- Improving the national standards in accordance with the European standards regarding the processing the enterprises at $30 \%$.

- The support for the agro-tourism in these regions for over 50 activities through the diversification of non-farm activities (outside the farm, handy craft).

- Increasing awareness (awareness) and capacities of the actors involved in the rural development and the development of the agro-food sector; the awareness of the agricultural and the agro-food quality.

- Increasing the demand for new projects in the agriculture and the rural development due to the increased awareness by the beneficiaries about the economic advantages and opportunities offered by the IPARD-Like program.

- Increasing the number of applications by the women to impact the growing number of women entrepreneurs in Albania. 


\section{The Problems Observed during Implementation}

- The preparation of public extension services in the counties to distribute information and advice to farmers and agri-businesses to IPARD measures, is at a satisfactory level, but their role is waning, as the farmers or the applicants tendency is towards private consultants, which has increased the costs of the application.

- The unclassified applications due to lack of the ownership titles.

\section{Summary Table}

Number of Applications by Call: Total

\begin{tabular}{|c|c|c|c|c|}
\hline District & 1-Call & 2-Call & 3-Call & Total For The Three Calls \\
\hline Berat & 06 & 00 & 01 & 07 \\
\hline Diber & 08 & 06 & 05 & 19 \\
\hline Durres & 07 & 06 & 11 & 24 \\
\hline Elbasan & 02 & 01 & 08 & 11 \\
\hline Fier & 11 & 09 & 16 & 36 \\
\hline Gjirokaster & 09 & 07 & 10 & 26 \\
\hline Korçë & 15 & 20 & 12 & 47 \\
\hline Kukes & 04 & 01 & 00 & 05 \\
\hline Lezha & 08 & 02 & 05 & 15 \\
\hline Shkoder & 06 & 05 & 03 & 14 \\
\hline Tirane & 08 & 03 & 17 & 28 \\
\hline Vlore & 00 & 05 & 18 & 23 \\
\hline Total & $\mathbf{8 4}$ & $\mathbf{6 5}$ & $\mathbf{1 0 6}$ & $\underline{\mathbf{2 5 5}}$ \\
\hline
\end{tabular}

\section{Conclusions}

Improving the quality of life in rural areas by increasing the competitiveness of the agricultural and agri-food policy through the application of the agricultural and the rural development policies.

Improving the national standards in accordance with the European standards regarding the fruit and vegetable and dairy meat of the farms.

The support for the agro-tourism.

Increasing the number of applications by the women to impact the growing number of women entrepreneurs in Albania

\section{References}

http://www.bujqesia.gov.al/

http://www.cbs.al/fo/pdf/20140723064922488.pdf

http://www.setimes.com/cocoon/setimes/xhtml/sq/features/setimes/features/2014/08/04/feature-01

http://www.azhbr.gov.al/component/content/article?layout=edit\&id=118

http://ec.europa.eu/enlargement/pdf/albania/ipa/2012/ipa_national_programme_albania_2012.pdf 